\title{
Screendance Cannot be Everything: Defining the Form Ten Years after the $(\mathrm{Hu})$ Manifesto
}

Wyn Pottratz, Independent Artist

Keywords: screendance, humanifesto, curator, opensource, video dance

At the recent Light Moves Festival of Screendance in Limerick, Ireland, I was sitting with screendance veteran Simon Fildes as we watched onscreen insects ready themselves for what looked to be a bug audition for National Geographic, minus the scientific commentary. One after another, bugs filled the screen primping their antennas, hanging on branches, spinning their cocoons or staring at other bugs. Curated into this hour-long screendance cinema program Boris Van der Avoort's made-for-gallery work "Imperceptible" dragged out for a lengthy fifteen minutes. Wilted in our seats, Fildes and I turned to each other, relaying the thought that crossed our minds - screendance cannot be everything surely?

Later in the festival symposium, Claudia Kappenberg talked about how experimental film or "expanded cinema," went through a similar ontological crisis in the 1960s and $70 \mathrm{~s}$ that is comparable to screendance today. ${ }^{1}$ Expanded cinema became so overwhelmed with its multiplicity of content that it became "bloated to the point of near meaningless," observed Jonathan Walley. ${ }^{2}$ As a result of ambiguity, expanded cinema morphed into other distinctive forms like "electronic art," "moving-image installation," and "new media." ${ }^{3}$ If screendance is limitless, then the field risks its status among other more definitive art forms, especially when it comes to funding or critical recognition. Kappenberg concluded with a proposition suggested by Walley that perhaps screendance needs its own "laundry list" of parameters to give the form some meaning, though this might be a fruitless task.

Though there are many ways to make a screendance, it may be time to fine-tune what constitutes the form and what does not. After all, the richer the discourse, the more an art takes its form. After a discussion with Fildes, we came up with our own definition: "Screendance is a moving image work, the content of which has choreographic compositional intention, combined with the technical and creative language of cinema." Van der Avoort's work, though visually alluring, demonstrated neither. Furthermore, there was no suggestion that it was made as a screendance, even though it was curated as one. 
Of course, as in dance and cinema, there are edges to definitions, and artists will push these edges. At the 2013 San Francisco Screendance Festival, I attended Siobhan Davies and David Hinton's screening of "All this Can Happen." This work clearly explores the boundary of screendance, re-imagining both filmic and choreographic possibilities in the editing suite, interweaving archival footage and language into an unexpected onscreen dance. "Choreography for the Scanner" controversially won the Leeds International Screendance competition last year by pushing the edges in an expanded cinema sense through the physical processes involved in its animation. It relies on the use of a scanner as a choreographic device, rather than an edit suite.

It's worth reflecting upon how screendance has gained a great deal of momentum in a relatively short period of time. Ten years ago, a group of artists and academics gathered in Findhorn, Scotland at a symposium called Opensource (Video Dance). At the end of the 4 days they drafted the (Hu)Manifesto: Possibilities for Screendance, a series of reference points intended to enrich the discourse within the field. It was an important step forward in creating "external prisms" for viewing work. ${ }^{4}$ Ultimately the list served as a framework for articulating meaning, as the authors put it:

This (Hu)Manifesto asserts that screendance has the potential to articulate metaphor, express conceptual concerns and manifest thematic possibilities. Inherent in the proposition of screendance is the possibility that through an accretion of images of bodies in motion, a larger truth may unfold.

- One that is greater than the impact of each moment experienced in isolation

- One in which sequential images in the context of dance on screen resonate with accompanying frames of reference to manifest a larger understanding of the world

- That in order to accomplish this, the screendance community must by necessity engage itself with rigorous critique that is grounded in both pre-existing and yetto-be articulated methodologies. ${ }^{5}$

The $(\mathrm{Hu})$ Manifesto resulted from practitioners and academics exchanging ideas at an event designed at its core to be communal. ${ }^{6}$ Organizers Jay-Lewin, McPherson, and Fildes believed that most conferences were so tightly scheduled, that little time remained for communication to develop organically. ${ }^{7}$ The organizers thought that deeper levels of discourse may evolve in a more "retreat-like setting," so they experimented with new session formats. One such session invited participants to roam the space, free to join or walk away from conversations at their own will. In this manner, the (Hu)Manifesto was drafted and debated on the final day of the symposium. Given the symposium's openness, it achieved incredible focus, evident through the (Hu)Manifesto. ${ }^{8}$

How knowledge is transferred and shared in the field is crucial to the autonomy of screendance. Though the (Hu)Manifesto was concerned with discourse not definition, 
the act of addressing issues in a range of frameworks allowed those present to be heard differently and ultimately set the stage for a definition. The 2006 and 2007 Opensource symposia's alternative modes of interaction increased the field's ability to traverse ideas, while strengthening its sense of community. As one participant commented, "Looking back now, I sense that screendance took a lurch forward during those four days in June 2006." ${ }^{\prime 9}$ The follow-up symposium that took place the following year in Findhorn created the framework for the development of the Screendance Network and The International Journal of Screendance.

Artists will continue to make work of all sorts, but it's the responsibility of curators and teachers who disseminates information to classify it. Through classrooms, festivals, and journals they hold the power to provoke and the space to invite reflection. And because exemplar screendance work is not particularly easy to find, the field relies heavily on these key individuals to shape experiences. The material they choose to include in their collections becomes the bedrock of the art form and feeds the future. "It always comes down to people, doesn't it?" remarks Claudia Kappenberg, Leader of the MA Performance and Visual Practices at University of Brighton. "It still relies on a massive effort of some very dedicated individuals." 10

Defining the taxonomy of screendance is a challenge perhaps best done by a group of such committed individuals. Now that screendance has moved to a certain level of maturity, perhaps it is time to hash out a new (Hu)Manifesto at another Opensource symposium with the current critically engaged community. When asked who are the individuals responsible for the next (Hu)Manifesto, Fildes responds "Whoever shows up are the right people."

\section{Biography}

American-born Wyn Pottratz is a choreographic filmmaker, dancemaker and movement educator soon-to-be based in Scotland. She received a graduate certificate in screendance under Ellen Bromberg and an MFA from the Modern Dance Department at the University of Utah. She was a recent member of the Bellingham Repertory Dance and owned Wyn Pottratz Pilates where she developed FLIGHT, a barre-inspired workout. Wyn has choreographed for musical theater, modern dance, and video. Fascinated by the geometry of bodies in space, yet irreverent to order, Wyn aims to create onstage worlds that deliver a sensorial experience.

Email: katpotz@gmail.com

Web: http://wyn.dance 


\section{Notes}

${ }^{1}$ Claudia Kappenberg, "The Politics of Discourse in Hybrid Artforms," 2.

2 Jonathan Walley, "Identity Crisis," 27.

3 Idem., 24.

${ }^{4}$ Katrina McPherson and Simon Fildes, "Opensource: Symposium," 17.

${ }^{5}$ Ibid.

${ }^{6}$ Fildes, "Opensource: (Video Dance)," 1.

7 lbid.

${ }^{8}$ Idem., 4.

${ }^{9}$ lbid. 4.

${ }^{10}$ Kappenberg, "Lightmoves."

\section{References}

McPherson, Katrina, and Simon Fildes. "Opensource: Symposium, 20th-24th November 2007, Findhorn, Scotland." Glenferness: Goat Media, 2009. Print.

Fildes, Simon. "Opensource: (Video Dance): New Models for Knowledge Transfer Between Practising Collaborative and Cross-Media Artists," 2007, unpublished. An adaptation of a paper presented by Katrina McPherson at the American Dance Festival, Screendance, State of the Art conference, USA, July 2006. 1-4.

Kappenberg, Claudia. "The Politics of Discourse in Hybrid Artforms." Paper given at Light Moves Festival of Screendance, Ireland, 20th November 2015. Published in Franck Boulègue and Marisa C. Hayes eds., Art in Motion: Current Research in Screendance / Art en mouvement : recherches actuelles en ciné-danse. Cambridge: Cambridge Scholars Publishing, 2015. 1-5.

Walley, Jonathan. "Identity Crisis: Experimental Film and Artistic Expansion." October 137 (Summer 2011): 24-29.

“Imperceptible.” Dir. Boris Van Der Avoort. 2015. Film.

"All This Can Happen." Dir. Siobhan Davies and David Hinton. Perf. John Heffernan. Sioban Davies Dance Production, 2013. Film.

“Choreography for the Scanner." Dir. Mariam Eqbal. 2015. Film.

Kappenberg, Claudia. "Lightmoves." Message to Simon Fildes. 4 February 2016. Email. 